\title{
Improving the performance of organizational innovation processes by applying the Six Sigma methodology
}

\author{
Ana Maria IFRIM \\ Titu Maiorescu University, Bucharest, Romania \\ amifrim@gmail.com \\ Gabriela Elena BIȚAN \\ Bucharest University of Economic Studies, Romania \\ Gabriela_Bitan@yahoo.com \\ Dorin MAIER \\ Technical University of Cluj-Napoca, Romania \\ Dorin.Maier@gmail.com \\ Teodora Elena FOGOROȘ \\ Bucharest University of Economic Studies, Romania \\ Teodora.Elena@icloud.com
}

\begin{abstract}
The purpose of this paper is to integrate the concept of innovation management with the Six Sigma methodology, focusing on the impact analysis of the quality management principles on the organizational innovation processes. To achieve this objective, the DMAIC methodology was used - define $(D)$, measure (M), analyze (A), improve (I) and control (C). Based on this methodology by introducing innovation in the improvement phase of the DMAIC model, we developed the model called DMAIC - IM (DMAIC - Innovation Management model). A case study related to the implementation of the DMAIC-IM Model was carried out within a company that produces and sells products for the automotive industry. Thus, the performances of the processes were measured, the obtained values were compared with the ideal values from a statistical point of view and the methods for eliminating the variations were identified. Also, the critical factors of the innovation success of organizations were analyzed resulting ways to remove the obstacles that lead to this success. According to the research results, the application of the Six Sigma methodology has a positive impact on the performance of the organizational innovation processes. The proposed solution has a set of indicators and can help organizations to improve their system of evaluating the innovation processes performances.
\end{abstract}

Keywords: Six Sigma, innovation processes, processes performance, performance indicators, quality management.

\section{Introduction}

In a global economy, when companies become increasingly dependent on knowledge, communication, progress efficiency, effectiveness and correct choice of products, processes and systems, at all levels and in all fields, innovation is, perhaps, the only way that any organization can surpass the competition, regardless of its size or the nature of its activity. Innovation, as a success factor in all sectors of an organization, implies the development of an optimal and systematic process that must be defined and implemented.

Innovation is present within many organizations that focus on optimizing its internal processes and ultimately increasing the added value of the business (Maier et al., 2017). Integrating the Six Sigma methodology with quality management and innovation management, an integrated 
approach is developed thus obtaining excellent results of the current activities (Olaru et al., 2010). The proposed approach can lead to new innovation opportunities that can achieve a high degree of productivity and a solid financial performance.

By integrating the concept of innovation management with the Six Sigma methodology, emphasis is placed on quality management principles to analyze the impact of the innovation process on the activities within an organization. Thus, the critical factors that underlie the success PICBE $\mid 1099$ of the organizations are analyzed and the methods of removing the obstacles that are in the way of this success are identified.

The Six Sigma methodology approaches the DMAIC model (Define, Measure, Analyze, Improve, Control) in order to reduce the variability of the processes through a deeper orientation towards innovation and implicitly towards the client. Thus, the perspective of understanding the critical points of each offered product or service will be improved, by making decisions based on the available values and the circumstances envisaged.

The results aimed by integrating the principles of quality management with the Six Sigma methodology are:

- Effective focus on customer's needs and expectations - increasing customer satisfaction;

- Increasing profit;

- Improving the quality of products / services;

- Increasing satisfaction among employees;

- Reducing the operating costs;

- Major recovery of the invested capital;

- As a mechanism for generating change management;

- Reducing the number of nonconforming products / services;

- Cultivate the extraordinary taste of excellence.

From the point of view of the approached methodology, DMAIC is an extremely rigorous project methodology that has the essential objective to increase the degree of capability and, at the same time, to reduce the defective identified in a process - optimizing the products, services or processes existing within an organization.

\section{Literature review}

In this paper we analyze the developed model based on the concepts of quality management, Six Sigma and innovation management. We consider that an integrated approach to a process is more effective if the organizations are forced to implement an innovation management system, if they want to stay in an increasingly competitive market.

Quality management plays an important role in an organization. There are different ways to choose the best approach to quality management: many organizations develop their own ways of working and strive to satisfy their customers in the best way possible, others adopt a quality management system based on the requirements of the international standard ISO 9001:2015 (Hellman et al., 2019).

Six Sigma methodology was developed as a statistical method to reduce the variation in the production processes of Motorola Inc.'s electronic components. Motorola states: "Six Sigma started as a defect reduction effort in manufacturing and was then applied to other business processes for the same purpose". Today, Six Sigma is seen as a management method that is based on data and statistical analysis that has the duty to evaluate the efficiency of a business and to improve it. 
Six Sigma is a systematic data-driven approach. In order to improve the existing process, the DMAIC methodology is used (Define, Measure, Analyze, Improve, Control) and for new product development the design Six Sigma method - DFSS is used (General Electric Company, 2004).

There are many important statistical tools and techniques that are systematically used at every stage of DMAIC and DFSS, in order to find the root cause of the problem and eliminate the PICBE | 1100 problem by applying effective improvement solutions. Among these, the following are considered to be more important: VOC (Voice of Customer), SIPOC Diagram (SIPOC = Supplier Input Process Output Customer), Statistical Process Control (SPC), Process Capability Analysis, Measurement System Analysis (MSA), Design of experiments (DOE), Quality Function Deployment (QFD), Failure mode and effects analysis (FMEA), Regression analysis, Analysis of variance, Root Cause Analysis, Process Mapping, etc.(Pyzdek, 2003).

In the scientific publications, the researchers consider that DMAIC is the most important place for application of the new knowledge created during the review after each phase (gate review), during the identification of root causes and during the problem-solving activities. All this developed knowledge can be shared and disseminated among the participants in the Six Sigma project teams.

Knowledge is a difficult concept to define. Nonaka and Takeuchi (1995) define knowledge as real justified beliefs. According to Pillania (2008) "Knowledge" is defined as an entire set of: intuition, reasoning, understanding, experiences related to technologies, products, processes, customers, markets, competition and so on, which allows for effective action.

In this context, Six Sigma has the responsibility to provide clarity in business, efficient organization, fewer errors in executing key business processes and reducing costs in a timely manner.

From the innovation point of view, we cannot talk about development within an organization if we do not approach this process (Olaru et al., 2013). The result of the innovation is a new product, service or process, a new method of marketing or organizing a business or which can lead to a significant improvement of what already exists (Toma, 2017).

Innovation is considered to be a success factor in all sectors of an organization and at all stages of the life cycle of a product (research - development, manufacturing, distribution and aftersales services) (SR 13572:2016 standard). It is also essential for business success to approach innovation as a concept of keeping up with competition through new products, services or ways of doing new things. (Naden, 2019)

Concerns regarding innovation are both at European and international level (Maier \& Dan, 2018; Olaru et al., 2013; Vadastreanu et al., 2015). The International Organization for Standardization (ISO), through the ISO / TC279 Working Group, has developed a new set of standards (ISO 56000) that will help organizations maximize their innovation management processes and achieve the best results from new ideas. In 2019, 3 standards from this series were published, and the other 5 standards are under development. At European level, the Technical Committee CEN / TC 389 - Innovation Management has developed the series of standards CEN/TS 16555. The first part of this series, published in 2013, is under review, and the other 6 parts have been confirmed until 2021. In Romania, the Technical Committee of ASRO, CT ASRO 383, published in 2016 the standard SR 13572:2016 - Innovation management systems. Requirements. 


\section{Methodology}

The main objective of the proposed model is to integrate the concepts of innovation management with the Six Sigma quality management methodology.

The proposed research methodology, from a quantitative but also qualitative point of view, also implies a practical approach. Quantitative methods were applied for statistical calculations of the measurement of process performance during the implementation of Six Sigma projects and PICBE | 1101 interpretation of data from the collected questionnaires. The qualitative methods have been applied for the analysis of a wide range of specialized literature, in order to propose a new model that integrates the Six Sigma methodology, the concepts of quality management and the innovation management.

The proposed methodology is based on the DMAIC model (table no. 1), which is an integrated conceptual model, which implies the development as part of the Six Sigma quality management system and which has tasks, tools, activities, management knowledge and methodology of evaluation for the performance of the innovation process.

The DMAIC cycle is a model of continuous quality improvement. As a structured approach, the model DMAIC (Define, Measure, Analyze, Improve, Control) (table no. 1) can provide solutions to a business.

Table 1. DMAIC Model

\begin{tabular}{|c|c|c|c|c|c|}
\hline Phases & Define & Measure & Analyze & Improve & Control \\
\hline Activities & $\begin{array}{c}\text { Defining the } \\
\text { current situation } \\
\downarrow \\
\text { Defining the } \\
\text { desired } \\
\text { situation }\end{array}$ & $\begin{array}{c}\text { Identifying } \\
\text { potential causes } \\
\downarrow \\
\text { Quantifying the } \\
\text { problem }\end{array}$ & $\begin{array}{c}\text { Analysis of } \\
\text { possible causes } \\
\downarrow \\
\text { Selection of } \\
\text { the initial } \\
\text { causes }\end{array}$ & $\begin{array}{c}\text { Identifying } \\
\text { potential solutions } \\
\downarrow \\
\text { Selection / } \\
\text { implementation of } \\
\text { solutions }\end{array}$ & $\begin{array}{c}\text { Effectiveness } \\
\text { control over time } \\
\downarrow \\
\text { Implementation of } \\
\text { control means }\end{array}$ \\
\hline Results & $\begin{array}{l}\text { Defining the } \\
\text { problem } \\
\text { Potential } \\
\text { advantages }\end{array}$ & $\begin{array}{l}\text { The origin of the } \\
\text { problem and the } \\
\text { list of causes }\end{array}$ & $\begin{array}{c}\text { Quantified } \\
\text { causes and } \\
\text { selected initial } \\
\text { causes }\end{array}$ & $\begin{array}{l}\text { Pilot solutions and } \\
\text { their final } \\
\text { implementation }\end{array}$ & $\begin{array}{l}\text { Control and } \\
\text { monitoring process } \\
\text { Confirmed benefits }\end{array}$ \\
\hline
\end{tabular}

As Six Sigma is a process optimization methodology, it is hoped that innovation management will become part of the process, so that the analyzed organization can have visible results. Innovation can be applied to both processes and products (Maier \& Dan, 2018). The processes include managerial-organizational processes, technological processes and marketing processes. Ultimately, marketing processes are also managerial processes consisting of promoting some products on the market through different methods.

\section{Development of the DMAIC - Innovation Management model}

Within the present methodology we will refer to the managerial-organizational processes and especially to those aimed at the correct sizing and accountability of the human resource within an organization, through the perspective of improving the quality of the products. 
Thus, by introducing innovation in the improvement phase of the DMAIC model, we developed the model called DMAIC - IM (DMAIC - Innovation Management model). This model is presented in table no. 2 .

Table 2. DMAIC - IM Model

\begin{tabular}{|c|c|c|}
\hline Phases & Activities & Tools and approaches used \\
\hline Phase 1 & $\begin{array}{l}\text { Planning the execution of the DMAIC-IM } \\
\text { phases }\end{array}$ & Six Sigma Concept \\
\hline Phase 2 & $\begin{array}{l}\text { Identification of activities for each } \\
\text { DMAIC-IM phase }\end{array}$ & ISO Checklist for Six Sigma \\
\hline Phase 3 & Using the tools for each activity & $\begin{array}{l}\text { Six Sigma tools used for each phase - FMEA, PDCA, } \\
\text { Kaizen }\end{array}$ \\
\hline Phase 4 & $\begin{array}{l}\text { Gathering new knowledge and ideas to } \\
\text { improve the process }\end{array}$ & Ideas management, Workshop, Brainstorming \\
\hline Phase 5 & Innovation management & $\begin{array}{l}\text { Development of the innovation process } \\
\text { Control of the innovation project } \\
\text { Modifications of the innovation project }\end{array}$ \\
\hline Phase 6 & Using of acquired knowledge & Running the project \\
\hline Phase 7 & Evaluation of the project performance & $\begin{array}{l}\text { Evaluation of the innovation process results } \\
\text { Analysis of the innovation process and its results } \\
\text { The impact of the innovation process } \\
\text { Estimation of the analyzed project added value in terms } \\
\text { of productivity indicators } \\
\text { Analysis of the efficiency and effectiveness indicators } \\
\text { Conclusions regarding the impact that the project has } \\
\text { on the organization } \\
\text { Ensuring continuity of the innovation process }\end{array}$ \\
\hline
\end{tabular}

\section{Implementation of the DMAIC - Innovation Management model}

The case study related to the implementation of the DMAIC-IM Model was carried out within a company that produces and sells products for the automotive industry, having a number of 200 employees in the production process, working in 3 shifts, 8 hours / shift. Of the 8 hours of work, about 30 minutes are lost for shift handover activity. The major problem that led to significant losses for the organization was that it had big delays in the production process, these delays increased the amount of penalties paid by the company to the customers, due to the fact that the products could not be delivered on time.

The production activities are complex, so after designing the product, it must go into production, to be tested and checked, packaged and in the end shipped to the customer.

Being a model of continuous quality improvement, the DMAIC-IM model (table no. 2) can provide for the business a series of solutions that can help organizations to solve their problems simultaneously from the beginning to the end, obtaining fundamental results.

Using the DMAIC-IM model we proceeded to define the problem. The considered process involves the production and verification of the finished products: activities of product realization, testing and verification, packaging and delivering of products. The process is synthesized presented in figure no. 1. 


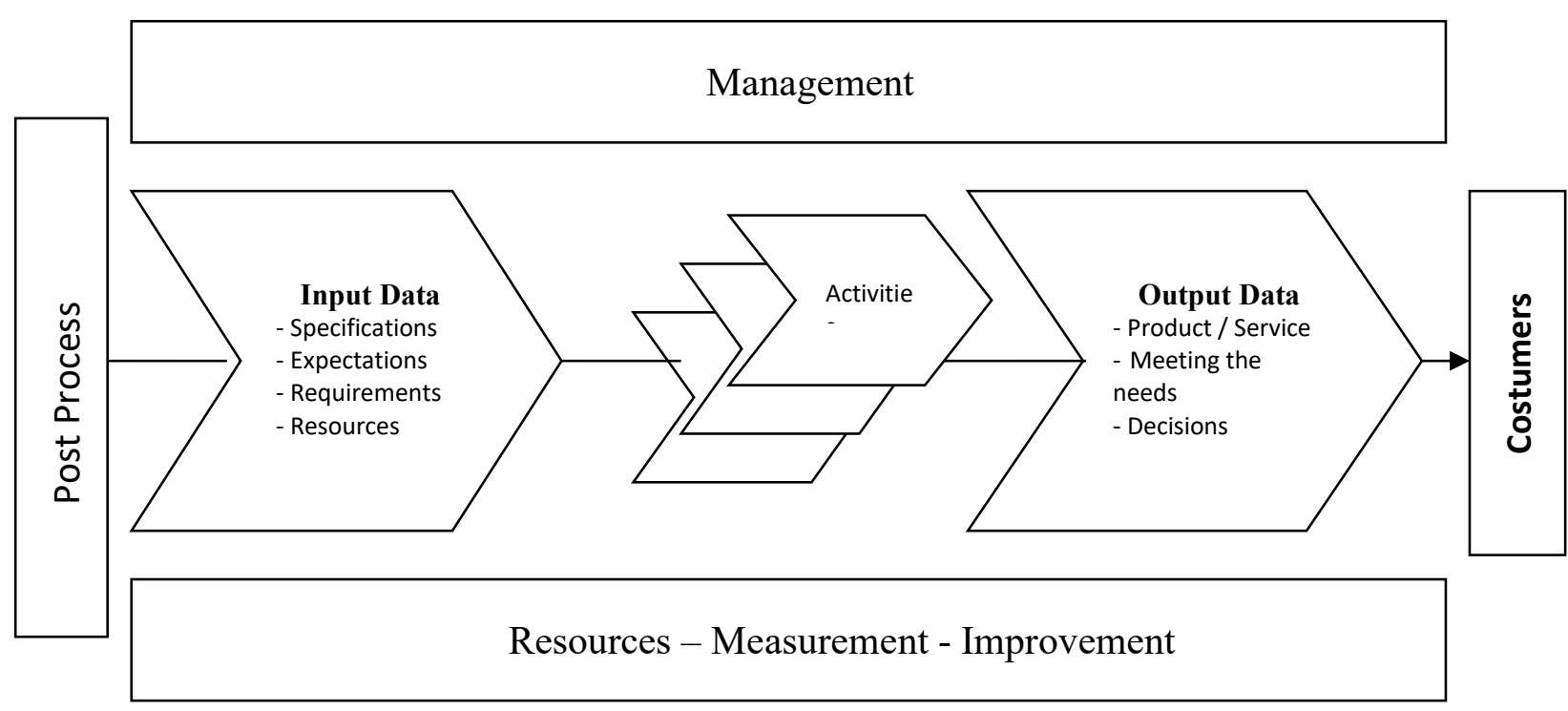

Figure 1. Schematic representation of the elements of a process

Source: Developed by the authors based on the standard SR EN ISO 9001: 2015 - Quality management systems. Requirements.

In first three phases of the DMAIC-IM project, the current stage of the production process was evaluated and it was found that the operational efficiency of the production process is insufficient (a production of about 50 products / person / week), generating overlaps, delays in the production process and a large number of nonconforming products. All this means that the completion of the operations regarding the production will not be carried out during the optimal delivery time of the finished product, the delivery day being Friday at 6 PM.

After evaluating the current state, in order to improve the production process, it is desired that the weekly finishing of the production activities should not exceed the day of Friday at 12 o'clock, and in case of volume, it is expected that the production should be 90 products / person / week.

Thus, by application of the tools related to the Six Sigma concept (FMEA, PDCA, Kaizen, Spaghetti Diagram), the analysis process was started, and the obtained results shows the possible causes for delays and waste:

- The overlap for a single worker of several activities

- Lack of optimization in the production area

- Inefficient production flows

- High waiting time for shift handover

- Lack of activity planning and labor standardization.

During the fourth phase, workshops and brainstorming sessions were held with both the top management staff and the production employees. All the ideas identified were evaluated and analyzed by the commission formed by the Production Manager, Innovation Manager, Quality Manager and Shift leader, taking into consideration the fundamental needs of the users, the marketing strategy, the degree of novelty brought, the legal factors, the technical-economic feasibility and the expected result.

In the fifth phase, the innovation process was developed, controlled and modified and objectives were set for the implementation of the innovation in accordance with the requirements 
of the standard SR 13572:2016 - Innovation management systems. Requirements. The objectives for the implementation of the innovation are presented in the table no. 3 .

\section{Table 3. Objectives for project implementation}

\begin{tabular}{|c|c|c|c|c|}
\hline Objective & $\begin{array}{c}\text { Actions for reaching the } \\
\text { goal }\end{array}$ & Responsible & Deadlines & Resou \\
\hline $\begin{array}{l}\text { Carrying out a much severe } \\
\text { planning of the activities for } \\
\text { the working section } \\
\text { personnel. }\end{array}$ & $\begin{array}{l}\text { At the } 8 \text { th working hours, } \\
30 \text { minutes will be added } \\
\text { for the shift handover } \\
\text { activity. }\end{array}$ & $\begin{array}{l}\text { Production Manager, } \\
\text { HR Director }\end{array}$ & 2 weeks & HR \\
\hline $\begin{array}{l}\text { Redesign of the production } \\
\text { space. }\end{array}$ & $\begin{array}{l}\text { Modifying the production } \\
\text { space so that it } \\
\text { corresponds to the } \\
\text { operational flow }\end{array}$ & $\begin{array}{l}\text { Production Manager, } \\
\text { Shift leader }\end{array}$ & 1 week & $\begin{array}{l}\text { Financial } \\
\text { Resources }\end{array}$ \\
\hline $\begin{array}{l}\text { Clearly define the processes } \\
\text { and responsibilities of each } \\
\text { worker so that there will not } \\
\text { be overlapping of activities } \\
\text { for one worker. }\end{array}$ & $\begin{array}{l}\text { Redefining organizational } \\
\text { charts and updating job } \\
\text { descriptions }\end{array}$ & $\begin{array}{l}\text { Production Manager, } \\
\text { HR Director }\end{array}$ & 1 week & HR \\
\hline $\begin{array}{l}\text { Integration into the } \\
\text { production activity of a } \\
\text { software that highlights the } \\
\text { production stage of each } \\
\text { product }\end{array}$ & $\begin{array}{l}\text { Software acquisition and } \\
\text { implementation }\end{array}$ & $\begin{array}{l}\text { Production Manager, } \\
\text { IT Manager }\end{array}$ & 4 weeks & $\begin{array}{l}\text { Financial } \\
\text { Resources }\end{array}$ \\
\hline $\begin{array}{l}\text { Displaying in the working } \\
\text { section of the work schedule } \\
\text { and the responsibilities }\end{array}$ & $\begin{array}{l}\text { Display at each working } \\
\text { point the responsibilities, } \\
\text { work schedule and breaks }\end{array}$ & $\begin{array}{l}\text { Production Manager, } \\
\text { Shift leader }\end{array}$ & 1 week & $\begin{array}{l}\text { Financial } \\
\text { Resources }\end{array}$ \\
\hline $\begin{array}{l}\text { Attending of the work section } \\
\text { staff to periodic training } \\
\text { programs. }\end{array}$ & $\begin{array}{l}\text { Establishing a periodic } \\
\text { training plan }\end{array}$ & $\begin{array}{l}\text { Production Manager, } \\
\text { Shift leader, HR } \\
\text { Director }\end{array}$ & 1 week & $\begin{array}{l}\text { Financial } \\
\text { Resources }\end{array}$ \\
\hline Decreased staff fluctuation & $\begin{array}{l}\text { Carrying out a staff } \\
\text { motivation program } \\
\text { according to the needs of } \\
\text { each employee }\end{array}$ & $\begin{array}{l}\text { Production Manager, } \\
\text { Shift leader, HR } \\
\text { Director }\end{array}$ & 4 weeks & $\begin{array}{l}\text { Financial } \\
\text { Resources }\end{array}$ \\
\hline
\end{tabular}

Source: Developed by authors based on the requirements of standard SR 13572: 2016 - Innovation management systems. Requirements.

In the sixth phase, using the acquired knowledge, the innovation project was launched by implementing actions to achieve the objectives set in the previous stage. This phase lasted 6 weeks.

In the last phase, the results of the innovation process were evaluated, both the whole innovation process, the results obtained and also the impact of the innovation process on the organization were analyzed.

\section{Description of the analyzed indicators}

The organization must constantly develop tools and methods that lead to increased efficiency and effectiveness. The increase of the two indicators and implicitly of the productivity, lead to the development of ways to improve the business. In the specialized literature, we find numerous definitions of these indicators. By combining the two indicators - effectiveness and efficiency, the company produces faster and more quality products, with fewer resources, because an effective 
employee performs the tasks at a high level, while an efficient employee is fast and intelligent (Stojcic et al., 2018).

Thus, effectiveness represents the quality of the actions results performed by the employees, which means that the effectiveness of the workforce has a huge impact on the quality of the product or service offered by the organization (Parast, 2011). We can say that effectiveness reveals the degree of achievement of objectives and is measured by comparing the obtained results with the PICBE $\mid \mathbf{1 1 0 5}$ desired ones.

From the point of view of efficiency, we can say that this indicator is transposed in the time necessary to complete the production activity. Efficient employees perform their tasks as quickly as possible, with the least possible resources, using certain time-saving strategies (Juhani et al., 2016).

Even if effectiveness and efficiency are mutually exclusive, ie an efficient employee is not always effective and vice versa, we can say that if the efficiency increases, the productivity increases also so that time and money are saved, and effectiveness ensures the quality of the final result, which ultimately is the organization's business card. Taken as a whole, efficiency is measured by reporting results to effort.

In order to improve effectiveness, the organization must provide a detailed performance analysis, detailing the employee's weaknesses through constructive criticism. From the efficiency point of view, the improvement of this indicator implies the involvement of all the targeted personnel in defining the means of increasing the efficiency in the workplace.

Because efficiency is closely linked to labor productivity, this was the next indicator analyzed. Labor productivity is considered the most relevant indicator used in economic analyzes, because it represents the ability of the labor force to create a certain volume of units (goods and services) over a period of time. (National Institute of Statistics, 2002). The level of labor productivity is measured by the quality and quantity of the goods obtained and the services provided in a work unit.

The indicators defined above have the same approach in the SR EN ISO 9000: 2015 Quality management systems standard. Fundamental principles and vocabulary: "efficiency - the degree to which the planned activities are carried out and the planned results are obtained", "effectiveness the relation between the obtained result and the resources used".

\section{Results and discussions}

At 6 months after the implementation of all stages of the DMAIC-IM model, the results were measured and analyzed. These results are presented in table no. 4.

Table 4. The results obtained at six months after the implementation of the DMAIC-IM project

\begin{tabular}{lcc} 
Indicator & $\begin{array}{c}\text { Value before applying the } \\
\text { DMAIC-IM model }\end{array}$ & $\begin{array}{c}\text { Value after applying the } \\
\text { DMAIC-IM model }\end{array}$ \\
\hline Effectiveness & $56 \%$ & $89 \%$ \\
Efficiency & 0,06 & 0,09 \\
Work productivity & 88,89 & 133,33
\end{tabular}

Source: Developed by the authors based on the developed methodology. 
After implementing the DMAIC-IM methodology, the production reached 80 products / person / week. From the increase of the production and from the values presented in table no. 4 it can be observed that the methodology had the expected impact. Effectiveness increased by 33 percent, efficiency increased by 0.03 , and labor productivity rise from 88.89 to 133.33 .

Six Sigma goes beyond the classical concept of organizing companies vertically, in an integrated one oriented horizontally on processes. By integrating Six Sigma with the concept of PICBE $\mid 1106$ innovation management this approach has resulted and it has a positive impact on the final product and implicitly on the turnover of the organization. The working method consisted in analyzing the current organization of the company from the production process point of view by emphasizing the impact that the human resource has on it.

Thus, the study highlighted within the company structure some organizational deficiencies due to repetitive processes, activities that do not add value, personnel fluctuations, lack of work planning at different stages of the production process, lack of optimization of the production space and inefficient production flows. For these deficiencies, solutions have been identified to obtain a rational work organization, to better respond to customer demand, to increase the efficiency of the company, with benefits over the competitiveness in a global market. The proposed indications with improvements and solutions, compared with the imposed standards, demonstrate the validity of the implemented project that is based on the concepts of Six Sigma, innovation management and quality management.

\section{Conclusion}

The application of the DMAIC-IM methodology has led to the development of solutions in order to increase the efficiency, effectiveness and implicitly of the productivity of the organization. It is known that productivity growth is of particular importance for organizations. Increased labor productivity has a logical character, assuming the change of production flows, so that the same volume of work acquires the force to produce a greater quantity of goods. Within the proposed methodology, the factors that influence the productivity level were taken into account: the technical factors (in the production process performant machnies are used), the economic factors (the quality of the labor force), the problem that appeared in the analysis process, the social factors (the responsibility of the human resource involved in the production process), the psychological factors (the work motivation, the labor relations climate and the analysis of the human resource needs).

The top management of the organization considers that the implementation of this project has been a success and they wish to continue developing other innovation projects throughout the organization, based on the DMAIC-IM methodology.

\section{References}

Black, K., \& Revere, L., (2006). Six Sigma arises from the ashes of TQM with a twist, International Journal of Health Care Quality Assurance, 19(2/3), 259-266.

Chang, S.-I., Yen, D.C., Chou, C.C., Wu, H.C., \& Lee, H.P. (2012). Applying Six Sigma to the management and improvement of production planning procedure's performance. Total Quality Management \& Business Excellence, 23(3), 291-308.

Chen, S., Chen, K. \& Hsia, T. (2005). Promoting customer satisfaction by applying Six Sigma: an example from the automobile industry, The Quality Management Journal, 12(4), 2133. 
El Manzani, Y., Sidmou, M.L., Cegarra, J., (2019). Does IS0 9001 quality management system support product innovation? An analysis from the sociotechnical systems theory, International Journal of Quality \& Reliability Management, 36(6), 951-982.

Hellman, P., \& Liu, Y. (2013). Development of quality management systems: how have disruptive technological innovations in quality management affected organizations?,Kvalita Inovácia Prosperita / Quality Innovation Prosperity, XVII/1.

Juhani U., Minna S., Satu P., Tero R., Juho S., Sanna P.,\& Martti M. (2016). Effectiveness of innovation capability development methods, Innovation, 18(4), 513-535.

Luburić, R. (2019). A Model of Crisis Prevention (Based on managing change, quality management and risk management), Journal of Central Banking Theory and Practice, 2, 33-49.

Maier, A., \& Dan, H.S., (2018). Influence of the Marketing Innovation on the Organizational Performance .International Journal of Advanced Engineering and Management Research, 3(6), 182-192.

Maier, D. Irmer S., J. Astrid F., \& Maier, A. (2017). Development and Operationalization of a Model of Innovation Management System as Part of an Integrated Quality-EnvironmentSafety System. Amfiteatru Economic, 19(44), 302-314.

Nonaka, I., \& Takeuchi, H. (1995). The knowledge-creating company. How Japanese companies create the dynamics of innovation. Oxford: Oxford University Press.

Olaru M., Hohan A., Maier A., \& Maier D., (2013) Metrics for Innovation of Product - the Basis for Continuous Improvement of an Organization. Science Journal of Business and Management. 1(1), 26-30.

Olaru, M., Dinu V., Stoleriu, G., Şandru, D., \& Dincă, V., (2010). Responsible Commercial Activity Of SMEs And Specific Values Of Sustainable Development In Terms Of The European Excellence Model, Amfiteatru Economic Journal, 12(27), 10-26.

Pamfilie, R., \& Procopie, R. (2013). Design si estetica in business. Bucharest: ASE Publishing House.

Pande, P., \& Holpp, L.(2002).What is Six Sigma?, E book. New York: McGraw-Hill.

Pande, P., Neuman, R., \& Cavanagh, R. (2000). The Six Sigma way.New York: McGraw-Hill.

Pande, P.S., Neuman, R.P., Cavanagh, \& R.R. (2002), The Six Sigma way, Team Fieldbook: An Implementation Guide for Process Improvement Teams. New York: McGraw-Hill.

Parast, M. M. (2011). The effect of Six Sigma projects on innovation and firm performance.International Journal of Project Management, 29(1), 45-55.

Pillania, R.K. (2008). Strategic issues in knowledge management in small and medium enterprises (SMEs). Knowledge Management Research and Practice, 6(4), 334-338.

Popescu, M., \& Mândru, L. (2016). Relationship between Quality Planning and Innovation, Bulletin of the Transilvania University of Brassov, Series V: Economic Sciences, 9((58)2).

Psomas, E., Kafetzopoulos, D., \& Gotzamani, K. (2018). Determinants of company innovation and market performance. The TQM Journal, 30(1), 54-73.

Pyzdek, T., (2003). The Six Sigma Handbook: A Complete Guide for Green Belts, Black Belts, and Managers at all Levels. New York: McGraw-Hill.

Schwab, K. (2016). The Fourth Industrial Revolution. Geneva: World Economic Forum.

Stojcic, N., Hashi, I., \& Orlic, E. (2018). Creativity, innovation effectiveness and productive efficiency in the UK, European Journal of Innovation Management, 21(4), 564-580.

Teodoru, T. (2019). Consideraţ̧ii cu privire la sistemele de management. Tehnică şi management. Obiecte şi obiective, CERTIND, 23, 30. 
Toma, J. (2017). Un nou standard pentru îmbunătăţirea procesului de inovare.Retrieved from https://www.ttonline.ro/revista/management-calitate/un-nou-standard-pentruimbunatatirea-procesului-de-inovare, accessed on 29.05.2019.

Troshkova, E. V., \& Levshina, V. V. (2018). Quality management system of complex economic entity as organizational innovation.International Journal for Quality Research, 12(1) 193-208.

Vadastreanu, A.M., Maier, D., \& Maier, A.(2015).Business success by improving the innovation management. In Proceedings of the 14th International Conference on Informatics in Economy International Conference on Informatics in Economy, Education, Research \& Business Technologies.

Vujović, A., Jovanović, J., Krivokapić, Z., Peković, S., Soković, M., \& Kramar, D. (2017). The relationship between innovations and quality management system. Tehnički vjesnik, 24, 551-556.

West, J. E, \& Cianfrani, C. I. (2015). Innovation and ISO 9001:2015.Quality Progress, 48(5), 5557.

Womack, J.P., \& Jones, D.T., (2008). Lean Thinking. Per i Manager che cambieranno il mondo. Milano: Guerini e Associati.

*** SR EN ISO 9000:2015 - Quality management systems - Fundamentals and vocabulary

*** SR EN ISO 9001:2015 - Quality management systems - Requirements

*** SR 13572:2016 - Innovation management systems. Requirements

*** ISO/DIS 56000 - Innovation management. Fundamentals and vocabulary

*** National Institute of Statistics (2002). Metodologia de calcul a productivităţii muncii în industrie, cod MSI 3, aprobată prin Ordinul nr. 232 din data de 28.05.2002.

*** https://www.sixsigma-institute.org/ accessed on 27.05.2019

*** https://www.iso.org/committee/4587737/x/catalogue/p/0/u/1/w/0/d/0, accessed on 24.10.2019

***https://shop.bsigroup.com/ProductDetail/?pid=000000000030272486 accessed on 24.10.2019

***http://magazin.asro.ro/ro/standard/245982 accessed on 24.10.2019

***https://ayatsaleh.com/2017/09/12/the-integration-between-quality-management-and-riskmanagement-systems/, The Integration between Quality Management and Risk Management Systems, 2017, accessed on 24.06.2019 